\title{
Hvorfor skal jeg elske min næste?
}

Nyborg, Ole

Published in:

Kirke og Kultur

Publication date:

2011

Document version

Også kaldet Forlagets PDF

Citation for published version (APA):

Nyborg, O. (2011). Hvorfor skal jeg elske min næste? Kirke og Kultur, 4, 305-313. 
Det, som gør en forskel for mennesker på denne jord, er ifølge N. F. S. Grundtvig at de kommer ud af den sump, nød og elendighed hvori de er havnet. Kærligheden til næsten skal gøre en virkelig forskel for næsten og det fortolkede Grundtvig på den måde at dette medmenneske skal lære en ny godhed og nye evner og på den måde få nye reelle muligheder for at leve et godt liv.

\section{Hvorfor skal jeg elske min næste?}

Kærligheden til næsten eller medmennesket har spillet en vigtig rolle i den kristne kirkes historie. Men hvad er egentlig meningen med denne kærlighed til næsten, og hvorfor skal jeg elske min næste? På hvilken måde skal man forstå den relation, som opstår mellem mig og min næste, når jeg stræber efter at elske min næste? En mulig måde, hvorpå man kan besvare sådanne spørgsmål, er at konsultere tekster fra den kristne kirkes historie. I det følgende skal gives en sammenfattende analyse af de tanker om kærligheden til næsten, som vi kan finde hos den danske teolog og prædikant N. F. S. Grundtvig (1783-1872).

DET ER TYDELIGT, AT EN AF DE Vigtigste POINTER, som N. F. S. Grundtvig havde i forbindelse med sin tale om kærligheden til næsten, var at sige, at

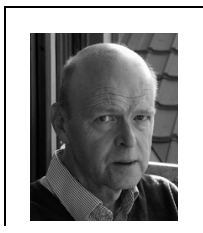

OLE Nyborg (F. 1948) Ole Nyborg, lektor, cand. mag., Ph. D.-studerende ved Teologisk Fakultet, Systematisk Teologi, Københavns Universitet. 
teologerne og filosofferne ude i verden talte ivrigt og ofte om kærligheden, men at de ikke havde nogen sand forståelse af denne kærlighed.

I en af sine prædikener siger Grundtvig således:

«Derfor er der endnu en Ting for os at giøre, den nemlig at vogte os for alle de falske, tomme og unaturlige Indbildninger om Kiærlighed, som vi enten selv har optænkt eller fundet hos de Verdsligvise». ${ }^{1}$

I den danske og ikke-danske Grundtvig-forskning er Grundtvigs tanke om kærligheden ofte blevet fortolket på den måde, at Grundtvig fokuserede på kærligheden til de nærmeste, de mennesker, som vi naturligt er knyttet til, børn, ægtefæller, venner eller landsmænd altså mennesker, som vi har et spontant eller naturligt forhold til. Men denne fortolkning af Grundtvigs kærlighedstanke er - som det skal fremgå af det følgende - ikke i overensstemmelse med Grundtvigs egne formuleringer.

Grundtvig modstillede i sine tekster konsekvent den naturlige kærlighed med den sande kærlighed. Om den naturlige kærlighed siger Grundtvig i en af sine prædikener:

«Det er ikke med Ord og Tunge men med Gierning og Sandhed, der skal elskes; thi hvem agter det vel for Andet end Falskhed eller dog Fjas og Tant hvor ømt og kiærligt en Moder taler om og til sine Børn eller ÆgteFæller om og til hinanden». ${ }^{2}$

Herudfra kan man spørge: Hvad var ifølge N. F. S. Grundtvig en sand form for kærlighed til næsten? I det følgende skal Grundtvigs svar søges forklaret ud fra tre spørgsmål, hvor forskellige ord er pointeret i den samme sætning, nemlig: Hvorfor skal jeg elske min noeste? Hvorfor skal jeg elske min næste? Og til sidst: Hvorfor skal jeg elske min næste?

\section{Hvorfor skal jeg elske min næste?}

Det første spørgsmål, som Grundtvig forsøgte at besvare i sine tekster, kan formuleres således: Hvorfor skal jeg eller hvorfor skal et kristent menneske lige netop elske ham eller hende, som er min eller det pågældende kristne menneskes næste eller medmenneske?

Svaret i Grundtvigs tekster er, at jeg skal elske denne næste, fordi han helt åbenlyst er dårligere stillet og meget svagere, end jeg selv er. Når jeg møder 
min næste, opstår der en relation, som ligner relationen mellem den barmhjertige samaritaner og den halvt ihjelslåede mand på vejen i evangelieteksten hos Lukas i Det ny Testamente. Relationen mellem de to parter er ifølge Grundtvig helt ulige. Man kan ikke ifølge Grundtvig med rimelighed sige til den halvt døde mand, som ligger på vejen, at han skal elske sin næste.

Grundtvig har derudover en vigtig pointe: Det er klart som solen og helt åbenlyst, at det er manden og ikke samaritaneren, som har brug for hjælp. Det, som er det gode, gavnlige og lykkelige for et menneske, er ikke et spørgsmål om smag og behag. Goder, værdier og normer værditeori objektive, og de er en del af den virkelige verden. Ifølge Grundtvig er det gode, rigtige eller værdifulde noget, som vi kan se, og derfor noget, som vi kan vide noget om. Ethvert fornuftigt menneske kan se, at den forulykkede mand er ham, som har brug for hjælp, og at han $\mathrm{i}$

Min næste er et menneske, som er gået helt fortabt al fald i jordisk forstand er gået helt fortabt.

Det er interessant, at vi på den måde finder en værditeori hos Grundtvig, som svarer til den «moralske realisme», som i nutiden er blevet forsvaret inden for den såkaldte dydsetik. ${ }^{3}$ Det, som er det gode og værdifulde, er noget, som vi kan se og erkende, og noget, som findes derude i den virkelige verden. Grundtvigs moral- og værditeori var på den måde en kritik af moralfilosofien hos den engelske filosof David Hume (1711-1776).

Min næste er, ifølge Grundtvig, et menneske, som er gået helt fortabt. Verden påstår at man ikke uden videre kan afgøre, hvem der er gået fortabt, eller hvem der er kommet ud i elendigheden. Verden påstår at et bestemt menneske ikke har nogen ret til at hævde, at et andet menneske er gåt fortabt. Grundtvig fastholdt i sine prædikener og øvrige tekster, at ethvert forstandigt menneske, som åbner øjnene og ser virkeligheden, som den er, kan se, at der er forskel på menneskers situation, og at nogle mennesker rent faktisk er havnet i en stor ulykke, elendighed og afmægtighed. Når jeg går ud fra, at min næste er havnet i en nød eller elendighed - som manden på vejen, der blev fundet af den barmhjertige samaritaner - så er min opfattelse ikke noget postulat, men en viden om den faktiske virkelighed.

Hvorfor skal jeg elske lige netop min noeste? Jeg skal ifølge Grundtvigs tekster elske ham eller hende, som lige nu er blevet min næste eller mit medmenneske, fordi dette menneske helt åbenlyst er svagere, mere ulykkeligt, 
mindre livskraftigt og mindre handlekraftigt, end jeg selv er, og fordi dette menneske helt åbenlyst ikke har de samme muligheder, evner eller ressourcer - som jeg selv har - for at klare sig godt igennem tilværelsen.

\section{Hvorfor skal jeg elske min næste?}

Det andet spørgsmål som Grundtvig søgte at besvare kan formuleres sådan: Hvorfor er det lige netop mig, som skal elske? Hvorfor er det lige netop mig, som skal elske min næste, og hvorfor er det ikke omvendt min næste, som skal elske mig?

Det svar, som vi kan finde i Grundtvigs tekster, går ud på, at relationen mellem mig og min næste er en helt ulige relation på samme måde som relationen mellem en fader og et barn og på samme måde som relationen mellem en mester og hans discipel. Over for min næste er det mig, som er den, der er større og stærkere, og som sidder med det naturlige ansvar. Når jeg handler ud fra den indsigt, at jeg er den, som er større og stærkere, handler jeg på en passende måde altså på en måde, som passer til den faktiske virkelighed.

Grundtvigs tanke er ikke, at jeg skal løbe rundt i verden og postulere, at jeg er større, klogere eller bedre. Hans tanke var, at i den faktiske relation mellem mig og min næste må jeg nødvendigvis handle ud fra, at jeg ved, hvad der er godt for min næste. Jeg kan ikke ifølge Grundtvigs tankegang bare spørge min næste, hvad han synes, at jeg skal gøre, for måske ved min næste ikke, hvad der tjener til hans fred.

I Grundtvigs tekster er der altså tydelige paralleller mellem forskellige relationer så som mesterens forhold til eleven, forælderens forhold til barnet og det kristne menneskes forhold til hans næste. Det var denne grundtvigske måde at trække paralleller på, som blev kritiseret i samtiden af hans modstandere. Men disse paralleller er tydeligt nok helt centrale i Grundtvigs opfattelse af kærligheden.

Grundtvig taler på den måde i en prædiken fra 1840 om det tunge ansvar, som ligger på det kristne menneske, som vil elske sin næste på en sand og virkelig måde, altså på en måde, som virkeligt kan gavne og nytte det andet menneske:

«Paa den anden Side kan vi dog ogsaa umuelig kiende Frelseren ret, uden at vide og mærke at han har en arrig, trædsk og uforsonlig Fiende, som 
maa forsages, hades og bestrides (...) vi kan heller ikke elske vore Medmennesker i Gierning og Sandhed, uden at ønske dem Himmerigs Glæde istedenfor Helvedes Kval, og giøre Alt hvad der staaer i vor Magt for at de ei skal lade sig forføre af Fienden men vende sig til Frelseren og holde urokkelig fast paa ham, saa de kan indgaae til Hans Herlighed». ${ }^{4}$

I den samme prædiken beskriver Grundtvig verdens opfattelse. Når Grundtvig i sine tekster talte om «Verden», refererede han mest til udbredte tanker hos samtidens forfattere, filosoffer og teologer. Verden mener ikke, at der eksisterer en djævel, og verden mener ikke, at man kan sige, at nogle mennesker er gået fortabt eller lever i den onde djævels rige. Grundtvig fremhævede heroverfor, at når vi skal elske vores næste, skal vi tage udgangspunkt $i$, at den onde djævels ånd er stærk og mægtig i denne verden, og at det, som vores næste har gavn og glæde af, er at blive trukket ud af synden, lidelsen og djævelskaben. Når vi skal elske vores næste, er det netop vores primære ansvar.

Verden anklager - som det fremgår af det følgende citat - Grundtvig for at «forkiættre og fordømme vore Medmennesker». Grundtvigs pointe i hans prædiken fra 1840 er heroverfor, at hvis vi stræber efter at elske vore medmennesker, må vi nødvendigvis gøre, hvad vi kan for at få dem til at indse, at de sidder fast i synden, svagheden, lidelsen, uvidenheden eller den onde vilje. Vel at mærke ifølge Grundtvig forudsat, at dette rent faktisk er tilfældet, og vel at mærke forudsat, at dette virkeligt er årsagen til medmenneskets og næstens nød og elendighed. Spørgsmålet om, hvorvidt det er årsagen til næstens nød og elendighed, er et spørgsmål, som nødvendigvis altid er op til det menneske, som ønsker at give en sand kærlighed til sin næste. Det spørgsmål må han afgøre med sin fornuft, viden og forstand, og han kan ikke uden videre blot spørge sin næste. Måske lever næsten i mørket, og måske ved denne næste ikke selv, hvad der tjener til hans fred:

«Ligesaalidt som der er noget Stalbroderskab mellem Ret og Uret, eller noget Fællesskab mellem Lys og Mørke, ligesaalidt er der noget Forlig mellem Christus og Belial. Vi veed det vel, at Verden kan slet ikke lide den skarpe Modsætning (...) men paastaaer langt heller, at Frelseren i Grunden slet ingen Fiende har, saa alt tilsyneladende Fiendskab mod Christus (...) vilde efterhaanden reent bortfalde, naar vi blinde Ivrere [Grundt- 
vig] (...) holdt op at forkiættre og fordømme vore Medmennesker. Ja (...) det veed vi Alle, er Verdens Dom, og har saameget smigrende for Kiød og Blod, at det er intet Under, selv Christne fristes til at tænke ligesaa, og vi (...) fristes da med det Samme til om ikke ganske at fortie, saa dog kun løselig at berøre den store Strid mellem Frelseren og Fienden; og Nødvendigheden af (...) at være fiendtlig sindet mod Alt hvad der bestrider vor Herres (...) Tro, som Han siger i Dagens Evangelium hvem der ikke er med mig, er imod mig, og hvem der ikke samler med mig, han adspreder». ${ }^{5}$

\section{Hvorfor skal jeg elske min næste?}

Det tredje spørgsmål, som Grundtvig arbejdede med i sine tekster, drejede sig om at definere selve kærlighedens natur og væsen. Hvad betyder det egentlig, at jeg lige netop skal elske min næste?

Som nævnt i indledningen afviste Grundtvig visse opfattelser af kærligheden, som i al fald ifølge Grundtvig var populære ude i verden. Verdens opfattelse er falsk og misvidende på en række punkter: (1) Den er individualistisk og ser relationer mellem mennesker som relationer mellem rene forskelsløse og lige stillede individer. (2) Den er værdi-skepticistisk og hævder på den måde, at det ene menneske aldrig kan afgøre, hvad der er godt for det andet menneske. (3) Den hævder, at kærligheden til næsten består i at give næsten det, som han beder om, uanset om denne næste ikke selv ved, hvad der tjener til hans fred. (4) Den har en urealistisk og naiv tro på og tillid til, at det naturlige menneske kan vælge at gøre det gode ud fra sine egne tanker og følelser. (5) Og endelig er verdens opfattelse af kærligheden statisk: Verden tror ikke, at mennesker kan opdrages, forandre sig, udvikle sig eller vokse i dyden, godheden og kærligheden. Verden hævder, at den menneskelige natur er, som den er, og det har den altid været.

I Grundtvigs tekster betyder det, at jeg skal elske min næste, det samme som, at jeg skal drage min næste ind $\mathrm{i}$ «Fuldkommenheds Baand». Hvis jeg vælger at elske min næste, bliver det muligt for min næste at blive et medlem af dette «Fuldkommenheds Baand». Forud for at jeg valgte at udvise denne kærlighed til min næste, var det ikke muligt for min næste at være et medlem af dette «Fuldkommenheds Baand». Det som ifølge Grundtvigs tekster er muligt for mennesker, når de lever inden for grænserne af «Fuld- 
kommenheds Baand», er at vokse i godheden og kærligheden, at erhverve sig nye evner og vaner, et nyt sind og en ny vilje, motivation og natur. For det menneske, som lever uden for «Fuldkommenheds Baand», altså for det menneske, som lever som et individ alene ude i verden - som den fortabte søn i det fremmede land - er det ikke muligt at erhverve sig nye evner eller vokse i godhed og kærlighed. De mennesker, som lever ude i verden altså uden for «Fuldkommenheds Baand», lever ifølge Grundtvigs prædikener «som afrevne Blade til Leg for Vindene». ${ }^{6}$

Grundtvig beskriver «Fuldkommenheds Baand» $\mathrm{i}$ en prædiken «2den Faste-Søndag 1833», hvor han prædiker over evangelieteksten om Jesu helbredelse af den kanaanæiske kvindes datter (Mattæus 15, 21-28). Det, som er det interessante i Grundtvigs prædiken, er, at han hævder, at den relation, som vi finder imellem Jesus og den kanaanæiske kvinde, i en vis overført forstand er et billede på den relation, som eksisterer eller bør eksistere i den sande virksomme og frugtbare kærlighed mellem en mand og hans næste.

Grundtvigs tanke er, at hvis jeg på en ansvarlig måde vil elske min næste, må jeg nødvendigvis indse, at min næste er langt svagere, end jeg er, og jeg må nødvendigvis påtage mig det ansvar at være en faderlig opdrager eller op-drager for min næste altså en, som kan og vil drage min næste ud af elendigheden, uvidenheden og lidelsen. Hvis jeg ikke vil påtage mig dette faderlige ansvar, giver jeg ikke min næste nogen slags kærlighed, som han kan have nogen nytte eller glæde af. Hvis jeg ikke accepterer og handler ud fra, at jeg er større og stærkere end min næste, så svigter jeg denne næste og gør ham i al fald ikke nogen stor tjeneste:

«Den lyksalige Kvinde (...) giver sig lydelig og tydelig tilkiende som hun der raaber efter ham: Herre, du Davids Søn! forbarm dig over mig, som, naar han tier og ligesom giør sig døv, trænger ind paa ham (...) og gientager trøstig sit: Herre! hjelp du mig! og som endelig naar han lader som han vil spise hende af med Steen for Brød, afvise hende haanlig, lader sig deraf hverken forbittre eller forvirre, men tager det for en Prøvelse (...) og giør det derved umueligt for Herren at skjule sig længer, lader sig gierne kalde en Hund, hvor det ikke giælder om et Been men om det Brød, hvis mindste Krumme mætter til et evigt Liv!» ${ }^{7}$ 


\section{Sammenfatning}

Når vi i dag læser Grundtvigs tekster, er det tydeligt, at der i disse tekster åbenbarer sig et sammenstød mellem en traditionel så at sige feudalistisk opfattelse og en såkaldt moderne menneske- og verdensopfattelse. De opfattelser, som Grundtvig angreb så voldsomt hos verdens filosoffer, forfattere og teologer, er netop de anskuelser, som siden har sejret som den «moderne» ånd.

Den danske og ikke-danske Grundtvig-forskning har ofte forsøgt at fortolke Grundtvig som en moderne mand. Denne Grundtvig-forskning har ikke sjældent tillagt ham den kærligheds- og menneskeopfattelse, som han netop angreb hos verdens filosoffer og teologer. ${ }^{8}$ Hvis man fortolker Grundtvig på den måde, kan hans tanker i en nutidig kontekst blive banale og dybest set uinteressante, og de kan i så tilfælde i al fald ikke fungere som et kritisk alternativ for nutidens mennesker.

Det, som gør en forskel for mennesker på denne jord, er ifølge N. F. S. Grundtvig. at de kommer ud af den sump, nød og elendighed hvori de er havnet. Kærligheden til næsten skal gøre en virkelig forskel for næsten og det fortolkede Grundtvig på den måde at dette medmenneske skal lære en ny godhed og nye evner og på den måde få nye reelle muligheder for at leve et godt liv.

Grundtvigs konklusion på den tanke var, at når jeg vil elske min næste, skal jeg påtage mig et ansvar og en rolle, som kan sammenlignes med den rolle, som en forælder har over for et barn, eller som en mester har over for en discipel. Det som virkeligt kan gavne en discipel, er ikke, at hans mester gør det, som han - disciplen - ikke selv kan gøre. Det, som for alvor kan gavne en discipel, er, at han selv lærer at gøre de ting, som er gavnlige, nyttige og nødvendige for ham $\mathrm{i}$ hans eget liv.

\section{Noter}

1 GPV II, 161-162. GPV bruges her som en forkortelse for: Jette Holm et al. (ed.): Grundtvig. Prædikener i Vartov, I-VIII, København: Forlaget Vartov 2003 og 2007.

2 GP IX, 243. GP bruges her som en forkortelse for: Christian Thodberg (ed.): N. F. S. Grundtvigs prædikener 1822-26 og 1832-39, I-XII, København: Gads Forlag 1983-1986. 
3 For eksempel: David McNaughton: Moral vision, Blackwell, Oxford 1988.

4 GPV I, 271-272: «3die Søndag i Faste 1840».

5 GPV I, 272.

6 GPV I, 26.

7 GP VI, 135.

8 Et nyligt eksempel er: Regner Birkelund: Frihed til fælles bedste. En oppositionel stemme fra fortiden. Aarhus: Aarhus Universitetsforlag 2008. Et ældre eksempel er: Kaj Thaning: Menneske først - Grundtvigs opgør med sig selv, København 1963.

\section{Publikationer:}

Nyborg, Ole (2010), «Grundtvig, dyden og kærligheden», Grundtvig Studier 2010, 96-126.

Nyborg, Ole (2010), «En kognitiv analyse af Grundtvigs begreb om 'Samfundet'», Religion. Tidsskrift for religionsloererforeningen for gymnasiet og HF. Nr. 4, december 2010, 52-61.

Nyborg, Ole (2010), «Kom Grundtvigs ‘søde Drøm’ om Danmark for tidligt?», Kristeligt Dagblad den 18. oktober 2010. Kronik

Nyborg, Ole (2010), «Fællesskaber er til, for at vi skal lære noget»,

Kristeligt Dagblad den 1. juli 2010. Kronik.

Nyborg, Ole (2010), «Er Grundtvig virkelig moderne?»,

Dansk Kirketidende nr. 6, juni 2010, 168-169.

Nyborg, Ole (2011), "Grundtvig, kristendom og politik»,

Dansk Tidsskrift for Teologi og kirke, nr. 2, 2011. 55-66.

Nyborg, Ole (2011), «Faderligheden», «Kiærligheden» og «Samfundet». Grundtvigs prædikener i Vartov især i kirkeårene 1847-1848 og 1848-1849.». Grundtvig Centerets konference: Grundtvig som samfundsbygger. Den 24. og 25. januar 2011. [http://grundtvigcenteret.au.dk/fileadmin/www.grundtvigcenteret.au.dk/ nyheder_og_arrangementer/arrangementsarkiv/ Grundtvig_som_samfundsbygger/Ole_Nyborg.pdf].

Nyborg, Ole (2011), «Grundtvig gik imod ideen om uhæmmet skrivefrihed», Dansk Kirketidende, 04, april 2011, 6-7.

Nyborg, Ole (2012, in print), «N. F. S. Grundtvig (1783-1872) og den såkaldt lystige kristendom», Dansk Tidsskrift for Teologi og kirke. 
For kvinner var karrieren å bli gift. Hvordan hun skjøtter rollen som hustru, mor og ansvarlig for en stor husholdning, beskrives i positive vendinger. Eventuelt gjengifte, hvor mange barn hun fødte, og hvor mange som levde opp, tas selvsagt med.

\section{Likprekener og liv i Norge på 1600-tallet}

Likprekener, en trykt sjangerform som oppsto etter reformasjonen, inneholder både en religiøs og en biografisk del. Denne artikkel tar for seg likprekenens biografiske del hvor det gis opplysninger om hvordan livet kunne arte seg for den mer etablerte del av befolkningen. Hvilken innsikt kan en likpreken gi av et kvinneliv på 1600-tallet?

AV ELISABETH S. EIDE

MARGARETHE SNELLE, SOM VAR FøDT I 1574 i Haderslev i Danmark, døde og ble begravet i Christiania i 1647. Hun utmerket seg ikke på noen måte, men hennes hverdagsliv har likevel vært dramatisk nok. Som datter av borgermesteren i Haderslev fikk hun en god kristelig oppdragelse, og en skolemester lærte henne å lese. Om hun også lærte å skrive, er uklart. Hun ble gift to ganger og fikk til sammen tolv barn. Etter at hun hadde blitt enke for annen gang, brøt krig og elendighet inn i hennes liv. Som 53-åring bestemte hun seg derfor til å flytte fra Haderslev til Christiania i 1627:

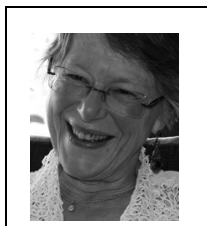

ELISABETH S. EIDE, (F. 1943) 1. amanuensis ved Nasjonalbiblioteket.dr. philos 1986 fra UiO på avhandling om China»s Ibsen. From Ibsen to Ibsenism. Utgitt:Vårt skjeve blikk på kineserne, Oslo 1995; Artikler i Nytt Norsk Tidsskrift og Library \&Information History. 